\title{
PEMBELAJARAN BAHASA DAN SASTRA BERBASIS KEARIFAN LOKAL SEBAGAI UPAYA OPTIMALISASI PENDIDIKAN KARAKTER MENUJU DUNIA GLOBAL Oleh \\ Leviana Disi ${ }^{1}$, Dwi Yuli Hartati ${ }^{2}$ \\ 1,2Program Studi Magister Pendidkan Bahasa dan Sastra Indonesia \\ Universitas PGRI Palembang \\ ${ }^{1}$ levianadisi@gmail.com
}

\begin{abstract}
Local wisdom in language learning and character reinforcement. In today's era of advanced communication intelligence is needed to utilize and package the values of local wisdom in a global context. In addition, no less important is the presence of creativity to bring back self-confidence in local behavior in national and global communications. Of course, the interpretation and creativity of literary authors become the basic necessity for maintaining local wisdom. Local color that is and carry the regionalism that is contained in crosscultural communication of course reflects keiindonesiaan and through literature also we can put the values of local wisdom so thick that can be poured in the form of novels, short stories and poetry. Through language learning can be a tool to maintain the identity or identity of the nation because in the Indonesian language contained image of Indonesia. The image can be constructed and constructed by the author through character, characterizations, background and place specificities, as well as the story situation in the language. The characteristics, nuances, and breaths of Indonesianness can be exchanged in the language. Because language and literature have the ability to concoct the values of locality that make the reader has wisdom and gave birth to a positive attitude in interpreting the value of local wisdom which is the identity of the nation.
\end{abstract}

Keywords - Language style satire of irony, cynicism and sarcasm

\section{PENDAHULUAN}

Bahasa dan sastra sangat erat kaitannya dengan penanaman kearifan lokal bagi masyarakat atau pembaca. Berbicara masalah kearifan lokal perlu melihat sejarah atau dinamika kehidupan bangsa Indonesia. Pada dasarnya, persoalan karakter menjadi perhatian serius pada setiap masa, setiap generasi, bahkan setiap periode yang menyertai perjalanan bangsa. Hal itupun diakui oleh semua bangsa di seluruh dunia. Bagi bangsa Indonesia (dapat dispesifikkan menjadi masyarakat suku bangsa), persoalan kearifan lokal telah disadari sejak awal kemerdekaan hingga masa kini. Persoalan kearifan lokal telah mengikuti dinamika perjalanan bangsa Indonesia.

Kearifan lokal dalam pembelajaran bahasa dan penguatan karakter. Pada era komunikasi canggih sekarang ini diperlukan kecerdasan memanfaatkan dan mengemas nilai-nilai kearifan lokal dalam konteks global. Di samping itu, tidak kalah penting adalah hadirnya kreativitas untuk menghadirkan kembali rasa percaya diri dalam berperilaku lokal dalam komunikasi nasional dan global. Sudah barang tentu penafsiran dan kreativitas pengarang sastra menjadi kebutuhan pokok. Kondisi itu disadari oleh pengarang masa kiri yang memiliki trend untuk menghadirkan karya 
sastra dari sumber sastra tradisi dalam formal sastra modern. Kondisi itu dapat dimaknai sebagai kerinduan sekaligus pengakuan bahwa nilai lokal masih layak dimanfaatkan dalam mendukung pembentukan karakter global. Masyarakat dapat membaca hadirnya novel, cerpen, drama, puisi sastra Indonesia modern yang mengambil sumber dari sastra tradisional (Suyitno, 2016).

Namun ketika moedernisme menyelinap ke dalam batang tubuh bangsa Indonesia, jebakan yang berujung pada keterpelantingan orisinilitas dan produktivitas kebudayaan asli tidak dapat dihindari. Arus teknologi-informasi telah menghancurkan batas-batas kebudayaan. Gelombang besar teknologi-informasi bukan hanya sekadar melintasi batas-batas kebudayaan, melainkan dapat memporandakan identitas kebangsaan. Identitas manusia sebagai bagian dari suatu kelompok masyarakat tidak lagi kuasa dipertahankan dari karakteristiknya. Perubahan yang mengakibatkan berubahnya mental dan watak, merupakan dampak dari perubahan budaya. Globalisasi telah terjadi dalam berbagai bidangnya, termasuk dalam bidang sains dan teknologi, sosial-politik, budaya, dan etika yang berimplikasi pada banyaknya masalah yang muncul dalam dunia pendidikan di berbagai Negara. Dunia baru yang ditawarkan peradaban masa kini hanya berhasil mengajarkan pragmatisme, kesementaraan hidup yang praktis (Naufal, dkk., 2014; Abdullah Idi, 2014; Rif'an, dkk.,
2012).

Indonesia sebagai Negara yang kaya akan budaya harus dapat membentengi diri terhadap gempuran dalam kancah percatruan budaya. Budaya bangsa harus diserap dan dijadikan sebagai karakter individu, masyarakat, dan bangsa. Akan tetapi jika melihat realitas, tampaknya Indonesia masih belum dapat memahami akar budaya bangsa sendiri sebagai identitas bangsa. Hal ini tampak begitu mudahnya para generasi muda mengadopsi budaya bangsa lain yang boleh jadi sangat bertentangan dengan tata nilai bangsa. Oleh sebab itu, sangat penting di era globalisasi sangat perlu penggalian kembali budaya yang dimiliki oleh bangsa Indonesia. Hal ini sangat krusial dilakukan dalam rangka membentengi arus pertukaran di era global. Basis-basis kearifan lokal yang ada dalam masyarakat perlu diangkat kembali.

Penggunaan aspek kearifan lokal dalam bahan ajar berarti mengangkat nilai lokal dalam pemahaman pemelajar. Nilai lokal ini akan menunjukkan identitas dan jati diri bangsa Indonesia. Pada saat informasi dengan sangat mudah diakses oleh siapa pun, kekuatan lokal akan mempunyai daya jual dan daya tawar yang tinggi. Nilai lokal yang unik inilah yang akan menjadi sebuah nilai jual dalam komunitas global. Hampir semua nilai lokal yang masuk dalam nilainilai kearifan lokal dapat dijadikan sumber dan inspirasi untuk memperkaya pengembangan nilai-nilai kehidupan. Beberapa penelitian menunjukkan bahwa 
kearifan lokal banyak membantu masyarakat dalam mempertahankan hidup.

Menurut Quaritzch Wales kearifan lokal merupakan kumpulan ciri budaya dari mayoritas masyarakat sebagai hasil dari pengalaman hidup mereka (Rahyono 2009:7). Pengertian itu menyangkut (1) ciri budaya, (2) sekelompok manusia sebagai pemilik budaya, dan (3) pengalaman hidup yang menghasilkan ciri budaya. Pendapat lain mengatakan bahwa kearifan lokal adalah sebuah kebijaksanaan setempat yang dikonsepsikan oleh masyarakat dan konsep tersebut mempunyai dampak daya tahan terhadap masalah yang timbul di masyarakat. Sebuah komunitas di masyarakat akan mempunyai cara tersendiri yang disesuaikan dengan kondisi masyarakat dalam memecahkan permasalahan yang mereka hadapi. Dengan demikian aspek yang muncul dalam kearifan lokal akan sangat menarik bagi pemelajar asing karena adanya aspek khusus mengenai ciri budaya, pemilik budaya, kebijaksanaan memecahkan masalah. Maka dari itu pembelajaran bahasa dan sastra dalam hal ini, memiliki potensi dalam upaya menawarkan dan menanamkan kearifan lokal bangsa pada generasi muda. Untuk itu, perlu adanya penanam kearifan lokal dalam pembelajaran bahasa dan sastra Indonesia.

\section{Pembelajaran Bahasa dan Sastra Sebagai Basis Menghadapi Dunia Global}

Bangsa Indonesia merupakan bangsa yang memiliki kekayaan nilai budaya yang beragam. Pada kenyataannya arus globalisasi telah membawa dampak terhadap nilai-nilai budaya bangsa. Globalisasi merupakan suatu fenomena yang berkembang cepat. Globalisasi membuat masyarakat bergerak terus dalam proses pengglobalan. Globalisasi sudah menyentuh hampir semua aspek kehidupan. Hal tersebut terjadi karena adanya kemudahan mengakses komunikasi, informasi, dan teknologi negara-negara maju. Globalisasi telah menciptakan berbagai tantangan dan permasalahan baru yang mesti dijawab dan dipecahkan. Akan tetapi, kita dapat memanfaatkan globalisasi untuk kepentingan kehidupan.

Globalisasi itu berlangsung di semua bidang seperti ideologi politik, ekonomi, pertahanan dan keamanan, serta sosial budaya. Dampak globalisasi di bidang sosial budaya sudah terasa. Kebudayaan moderndan global sudah merasuk ke dalam jiwa bangsa Indonesia. Nilai-nilai budaya lokal seperti nilai-nilai yang menyangkut etika, estetika, moral, agama, sosial, dan cara pandang diri sudah mulai terkikis, memudar, bahkan boleh jadi sudah sulit terlacak.

Dengan demikian, diperlukan suatu upaya untuk memperkukuh nilai-nilai karakter kebangsaan. Pemerkukuhan karakter kebangsaan sangat diperlukan untuk mengatasi ancaman, kendala, atau tantangan yang datang dari luar yang dapat mengancam kelangsungan hidup dan eksistensi produk budaya lokal. Upaya untuk 
mempertahankan dan memperkukuh jati diri bangsa, salah satunya ialah melalui bahasa dan sastra. bahasa Indonesia banyak mengandung nilai-nilai kearifan lokal. Warna lokal yang bersifat dan mengusung kedaerahan yang terdapat dalam komunikasi lintas budaya tentu saja mencerminkan keiindonesiaan dan melalui sastra pula kita bisa menaruh nilai-nilai kearifan lokal yang begitu kental yang dapat dituangkan dalam bentuk novel, cerpen dan puisi.

Melalui Pembelajaran bahasa dapat djadikan alat untuk mempertahankan jati diri atau identitas bangsa karena dalam bahasa Indonesia terkandung citra keindonesiaan. Citra tersebut dapat dikonstruksi dan dibangun pengarang lewat karakter, penokohan, kekhasan latar dan tempat, juga situasi cerita dalam bahasa itu. Karakteristik, nuansa, dan nafas keindonesiaan dapat diembuskan dalam bahasa. Dalam upaya menonjolkan identitas keiindonesiaan, pengarang dalam bahasa dapat juga mengetengahkan Indonesia yang lintas budaya, Indonesia yang terdiri atas kesatuan berbagai etnis, dan Indonesiayang memiliki hibriditas dan pluralitas. bahasa juga dapat dijadikan sarana mengembangkan dan membangun sikap moral, mental, ideologi, kontruksi berpikir, konsep budaya, kemanusiaan, dan kepedulian social

Pembelajaran bahasa dan sastra sangatlah tepat untuk mengangkat kearifan lokal karena melalui bahasa dapat disampaikan nilai-nilai sosial yang terjadi di daerah. Oleh karena bahasa memiliki kemampuan untuk meramu nilai-nilai lokalitas yang membuat para pembaca memiliki kearifan dan melahirkan sikap positif dalam memaknai nilai kearifan lokal yang merupakan identitas bangsa.

\section{Bahasa, Sastra dan Kearifan Lokal}

Dalam praktiknya, bahasa dan sastra mampu mengukuhkan nilai-nilai lokal yang positif dalam pikiran dan perasaan bangsa Indonesia. bahasa mampu menjadi alat penapis atau penyaring pengaruh dari luar. Dengan bahasa, kita bisa menjadi manusia yang kreatif, berwawasan, futuristik, dan berkualitas jika kita dapat menangkap nilainilai positif dalam bahasa. Menurut Djojonegoro (1984: 425) bahasa selain mampu memberikan nilai-nilai positif, juga dapat membantu mengembangkan sikap positif terhadap perkembangan ipteks yang tidak dapat dibendung itu.

Ridwan (2007: 2-3) mengatakan bahwa kearifan lokal atau sering disebut local Wisdom dapat dipahami usaha manusia dapat dipahami sebagai usaha manusia dengan menggunakan akal budinya (kognisi) untuk bertindak dan bersikap terhadap sesuatu, objek, atau peristiwa yang terjadi dalam ruang tertentu. Pengertian tersebut disusun secara etimologi, di mana wisdom dipahami sebagai kemampuan seseorang dalam menggunakan akal pikirnya dalam bertindak atau bersikap sebagai hasil penilaian 
terhadap suatu objek atau peristiwa yang terjadi. Sebagai sebuah istilah wisdom sering diartikan sebagai 'kearifan/kebijaksanaan'. Lokal secara spesifik menunjuk pada ruang interaksi terbatas dengan sistem nilai yang terbatas pula. Sebagai ruang interaksi yang sudah didesain sedemikian rupa yang di dalamnya melibatkan suatu pola-pola hubungan antara manusia dengan manusia atau manusia dengan lingkungan fisiknya. Pola interaksi yang sudah terdesain tersebut disebut setting. Setting adalah sebuah ruang interaksi tempat seseorang dapat menyusun hubungan-hubungan face to face dalam lingkungannya. Sebuah setting kehidupan yang sudah terbentuk secara langsung akan memproduksi nilai-nilai. Nilai-nilai tersebut yang akan menjadi landasan hubungan mereka atau menjadi acuan tingkah-laku mereka.

Kearifan lokal sebenarnya sangat berhubungan erat dengan kehidupan yang dijalani oleh manusia. Dimana kearifan lokal bisa tumbuh dan berkembang jika kehidupan manusia tetap berlangsung dan berjalan sebagaimana mestinya. Kearifan lokal bisa terus eksis ditengah dunia global jika manusia bisa menjaga budaya lokal dengan baik an benar. Salah satu cara untuk menjaga kearifan lokal itu adalah melalu bahasa dan sastra.

Koentjaraningrat (1984: 8-25) mengatakan bahwa nilai budaya adalah lapisan abstrak dan luas ruang lingkupnya. Tingkat ini adalah ide-ide yang mengkonsepsikan hal-hal yang paling bernilai dalam kehidupan masyarakat. Suatu sistem nilai budaya terdiri atas konsepsikonsepsi yang hidup dalam pikiran sebagian besar warga masyarakat mengenai hal-hal yang harus mereka anggap bernilai dalam hidup. Oleh karena itu, suatu sistem nilai kebudayaan biasanya berfungsi sebagai pedoman tertinggi bagi kelakuan manusia. Sistem kelakuan manusia lain yang tingkatannya lebih konkret, seperti aturanaturan khusus, hukum, dan norma-norma, semuanya juga berpedoman pada nilai budaya itu. nilai budaya yang dapat mendorong pembangunan, di antaranya sifat tahan penderitaan, berusaha keras, toleran terhadap pendirian atau kepercayaan orang lain, dan gotong-royong.

Dalam memandang sastra sebagai bagian dari kebudayaan di Indonesia, Ratna (2011: 10), permasalahan yang berkaitan dengan masyarakat dengan sendirinya lebih beragam sekaligus lebih kompleks dalam sastra regional, sastra nusantara. Indikator yang berkaitan dengan bahasa sebagai medium. Di Indonesia terdapat ratusan bahasa yang masih hidup dalam masyarakatnya masing-masing, sebagian belum pernah diangkat ke dalam suatu penelitian. Indikator kedua berkaitan dengan struktur sosial itu sendiri, yang berebedabeda sesuai dengan geografi, alam sekitar, iklim, maupun dalam kaitannya dengan ciriciri masyarakat yang mendukungnya. Seangkan Trianton (2015) mengatakan bahwa pada dasarnya sastra Indonesia 
adalah sastra lokal. Persoalan-persoalan yang ditulis oleh sastrawan merupakan persoalan yang bersumber dari budayabudaya lokal yang disebut etnik. Sastra menjadi dokumentasi budaya lokal, yang merupakan pembentuk identitas bangsa.

Dari pemaparan di atas, pada hakikatnya bahasa dan sastra Indonesia yang mengangkat tema-tema kearifam lokal sangat banyak dan beragam. Baik dalam bentuk puisi, novel, dongeng, cerita rakyat, novel, cerpen, maupun drama sangat banyak keberadaannya. Oleh sebab itu, sastra memiliki porsi penting dalam penggalian nilai kearifan lokal sebagai pembentuk karakter kebangsaan.

\section{Bahasa dan Sastra Sebagai Basis Pendidikan Karakter Kebangsaan}

Dalam UU Nomor 20 Tahun 2003 tentang Sistem Pendidikan Nasional Bab I Pasal I Ayat I dikatakan, "pendidikan adalah usaha sadar dan terencana untuk mewujudkan suasana belajar dan proses pembelajaran peserta didik secara aktif mengembangkan potensi dirinya untuk memiliki kekuatan spiritual keagamaan, pengendalian diri, kepribadian, kecerdasan, akhlak mulia, serta keterampilan yang diperlukan dirinya, masyarakat, bangsa, dan Negara". Dari pemaparan basis pendidikan sebagaimana diamanatkan oleh UNESCO, secara ekmplisit sangat relevan dengan citacita yang diamanatkan dalam UU Nomor 20 Tahun 2003. Proses pembelajaran secara aktif mengembangkan potensi diri untuk memiliki kekuatan spiritual keagamaan, pengendalian diri, kepribadian, kecerdasan, akhlak mulia merupakan bagian dari pendidikan berbasis karakter.

Dalam konteks kebudayaan, bahasa dan sastra memiliki posisi penting dalam pembentukan karakter bangsa. Demikian pula dalam porsi pembentukan mental, sebab dunia dalam sastra merupakan dunia yang dibangun atas dialektika ruang keindahan dan nilai. Sastra hadir dengan fungsinya sebagai bagian untuk mendidik masyarakat. Menurut (Ratna, 2014: 209) mengatakan bahwa karya sastra bersumber dari fungsi-fungsi karya sastra. Karya sastra sebagai kreativitas imajinatif yang sesungguhnya dari masyarakat, demikian juga karya budaya sebagai warisan, baik secara mandiri maupun proses antarhubungan, merupakan sumber utama karya pendidikan karakter. Dalam konteks ini, wahana edukatif karya sastra ialah media dalam pembentukan karkter. Baik pemahaman terhadap budaya bangsa maupun terhadap nilai-nilai yang terkandung dalam kebudayaan.

Bahasa dan sastra tidak hanya dipandang sebagai sebuah karya seni bahasa yang kosong nilai. Akan tetapi tidak demikian sempit, sastra sebagai hasil budaya sangat memiliki peran penting terhadap perkembangan kebudayaan. Bentuk realitas, nilai kemasyarakatan, sampai dengan keragaman kebudayaan suatu masyarakat merupakan aspek yang patut untuk kembali digali sebagai 
penguatan kebudayaan. Melihat hal ini, Wibowo (2013: 109) sastra harus bisa berperan human control persoalanpersoalan yang terjadi di masyarakat. Pandangan ini jelas sangat sesuai dengan prinsip bahwa setiap karya sastra yang dihasilkan oleh sastrawan terkandung misi. Dalam kontek demikian, Ratna (2014: 209) memberi penegasan bahwa setiap aktivitas memiliki fungsi, tujuan, dan hasil akhir, termasuk evaluasi dalam rangka perkembangan aktivitas tersebut. Demikian pula halnya sastra, relevansinya ditunjukkan melalui makna tambah yang berhasil ditunjukkan, baik oleh pecipta, sebagai subjektivitas, maupun penikmat, sebagai makna subjektivitas sekaligus objektivitas. Tidak ada karya sastra tanpa tujuan.

Oleh sebab itu, ada yang mengatakan bahwa peran sastra sebagai human control guna mengembalikan martabat manusia, baik di mata manusia lain, maupun di sisi Tuhan. Sastra adalah ruang pencarian dan bentuk pemikiran kritis yang dalam ruang tersebut mengemban nilai-nilai spiritual, kemanusiaan, sosial, serta nilai hakiki kehidupan lain. Maka dengan bahasa sebagai mediumnya, diharapkan satrawan harus mampu menghindari kepicangan ranah yang tanpa makna. Bahasa difungsikan satrawan sebagai bentuk olah pikir sehingga misi luhur yang diupayakannya dapat tertuang. Misi luhur tersebut adalah mengasah karakter kebangsaan pada generasi muda.

\section{Usaha} untuk sebagaimana tersemat dalam undangundang di atas secara yakni menyiapkan generasi yang berkarakter. Jika dikontekskan dengan abad 21 ini di mana dunia tengah memasuki era global, pendidikan yang mengarah pada pembentukan karakter kebangsaan sangat urgen dilakukan. Pertukaran informasi tidak disadari membawa pula pengaruh kebudayaan dari masyarakat bangsa dari belahan dunia. Pengadopsian terhadap nilai dari budaya lain pun tidak bisa terhindarkan oleh generasi bangsa. Melihat fenomena ini, pemerintah melalui Kurikulum 2013 merupakan usaha untuk mengantisipasi generasi digital dan usaha sadar merespon kehidupan global. Penanaman pendidikan karakter di Indonesi salah satunya diwujudkan melalui Kurikulum 2013 seperti pendapat Muhaimin (dalam Abdullah Idi, 2014: 264) mengatakan, perubahan KTSP ke Kurikulum 2013 sesungguhnya guna merespons dan mengantisipasi perkembangan, tuntutan kebutuhan masyarakat. Globalisasi telah terjadi dalam berbagai bidang, termasuuk dalam bidang sains dan teknologi, sosial-politik, budaya dan etika yang berimplikassi pada banyaknya masalah yang munncul dalam dunia pendidikan di berbagai negara.

Mempertimbangkan dua aspek penting di atas, yakni mengenai basis pendidikan karakter dalam Kurikulum 2013 dan sastra sebagai basis pembentukan karakter kebangsaan, kiranya sangat perlu dipadukan. Indonesia sebagai Negara yang 
kaya akan kearifan lokal sungguh sangat mungkin untuk memunguti kembali nilai-nilai yang terkandung di dalamnya. Tidak hanya itu, dalam karya sastra para pengarang sastra banyak mengambil tema-tema kearifan lokal yang direfleksikan dalam karyanya.

Dengan demikian, pembentukan karakter dapat disumbang pula oleh pembelajaran sastra di sekolah. Upaya ini tidaklain adalah sebagai usaha untuk menumbuhkan kesadaran mengenali dan membentuk kembali karakter kebangsaan yang selama ini dilupakan. Oleh sebab itu, pedoman pembelajaran sastra sangat penting untuk mempertimbangkan materi pembelajaran sastra yang sarat akan nilai kearifan lokal bangsa. Pembelajaran harus mampu membawa peserta didik kepada kehidupan.

Dalam hal ini, pembelajaran kontekstual dapat memberi dukungan terhadap pembelajaran sastra berbasis nilai kearifan lokal. Menurut Sujarwo (2011: 48) menyatakan, pembelajaran kontekstual merupakan konsep belajar yang membantu pendidik dalam mengaitkan materi pembelajaran dengan situasi dunia nyata peserta didik dan mendorong peserta didik membuat hubungan antara pengetahuan yang dimilikinya dengan kehidupan anggota keluarga dan masyarakat. Dalam proses pembelajaran, tugas pendidik mengelola kelas sebagai tim yang bekerja bersama untuk menemukan sesuatu yang baru bagi peserta didik. Pengetahuan dan keterampilan yang diperoleh merupakan hasil kerja mandiri peserta didik berdasarkan konsep yang dikaitkan dengan kondisi lingkungan tempat tinggalnya.

Peran peserta didik mengkontruksi informasi- informasi yang diperoleh untuk diformulasikan menjadi pengetahuan dan keterampilan yang dimiliki. Pembelajaran kontekstual dapat dipadukan dalam pembelajaran sastra berbasis kearifan lokal. Cara ini memberi peluang peserta didik dalam mengenal, menggali, dan menyerap nilai-nilai karakter dalam pembelajaran sastra.

\section{KESIMPULAN}

Dari pemaparan di atas bisa disimpulkan bahwa dalam dunia pendidikan. Penguatan karakter kebangsaan dapat dimulai dari optimalisasi pendidikan karakter berbasis kearifan lokal melalui pembelajaran sastra. Penekanan Afektif pada Kurikulum 2013 serta pembelajaran yang tematik integratif akan sangat memberi dukungan pada pendidikan karakter dalam pembelajaran sastra. Pembelajaran yang bersifat praktik terpadu dan kontekstual dapat memberi sumbangsih dalam menangkap isu-isu kearifan lokal dalam kebudayaan. Pengangkatan terhadap sastra nasional hingga sastra daerah perlu diakomodatif. Terlebih jika melihat sastra daerah di bangsa yang multikulutur seperti Indonesia harus digali kembali. Pembelajaran sastra berbasis pembelajaran kontekstual sangat relevan untuk diterapkan. 


Hal terpenting dalam $\begin{array}{r}\text { upaya } \\ \text { adalah }\end{array}$
penggalian karakter bangsa
penggalian dan penguatan terhadap
khazanah kebudayaan nasional. Bahasa
dana Sastra pada konteks ini akan mampu
menjadi paduan yang cocok untuk
penguatan akar karakter bangsa. Oleh
karena itu, peran pengarang, pendidik, dan
pengembang perlu
memperhatikan penghidupan bahasa dan
sastra dengan basis kearifan lokal.

\section{DAFTAR PUSTAKA}

Idi, Abdullah. 2013. Pengembangan Kurikulum Teori dan Praktik. Jakarta: Raja Grafindo Persada.

Koentjaraningrat, 1984. Kebudayaan, mentalitas, danPembangunan. Jakarta: PT. Gramedia.

Naufel, Ahmad dkk. 2014. Pancasila, Budaya Virtual dan Globalisasi. Purwokerto: STAIN Press.

Ratna, Nyoman Kutha. 2011. Paradigma Sosiologi Sastra. Yogyakarta: Pustaka Pelajar.

Ridwan, Norma. 2007. "Landasan Keilmuan Kearifan Lokal". Makalah dalam Jurnal Studi Islam dan Budaya Ibda'.Vol. 5. No. 1. Jan-Jun 2007. HIm. 27-38.

Sujarwo. 2011. Model-model Pembelajaran Suatu Strategi Mengajar. Yogyakarta: Penerbit Venus Gold Press.

Suyitno. 2009. Apresiasi Puisi dan Prosa. Lembaga Pengembangan Pendidikan (LPP) UNS dan UPT Penerbitan dan Percetakan UNS (UNS Press).

Trianton, Teguh. $2015 . \quad$ "Strategi Pemertahanan Identitas dan Diplomasi Budaya melalui Pengajaran Sastra Etnik Bagi Penutur Asing". Makalah dalam Konferensi Bahasa dan Sastra III, UNS, Surakarta

Wibowo, Agus. 2013. Pendidikan Karakter Berbasis Sastra. Yogyakarta: Pustaka Belajar. 